\title{
PAMULINAWEN: A HERMENEUTICS OF ILOKANO' CULTURAL SELF-UNDERSTANDING
}

\author{
Danilo S. Alterado \\ Saint Louis University, Baguio City, Philippines
}

\begin{abstract}
Aldrin S. Jaramilla
University of Northern Philippines, Vigan City, Philippines
\end{abstract}

This paper aims to institute that the folk song Pamulinawen is essentially a work of art descriptive of Ilokano cultural self-understanding. Specifically, it wants to elucidate that Pamulinanen, per se, is capable of self-assertion; it can usher itself to engage in a dialogue with the Ilokano beholder, and through the mediation of a common pagsasao (language), it embodies the individual and/or Nakem, the Ilokano collective identity. More than a popular song of courtship among the Ilokanos, the song Pamulinawen then attempts to increase knowledge about Ilokano kananakem (cultural self-understanding) so that it serves not only as a piece of Ilokano cultural entertainment but as a medium to express "Ilokano-ness" (Ilokano beingness). Through the qualitative methodology, this study mainly employs maiyannatup a panagripirip, a hermeneutical approach to appropriately philosophize on the Ilokano metaphysics, epistemology, and axiology. This approach consists of, among others, palpaliiw (observation) and the "Agcaoilon PAR" ("Punget-A-Ramut a balikas" or root-stem word).

\section{INTRODUCTION}

The philosophy of a people is dynamically formed within the context of their situatedness. They ordinarily examine themselves as individuals or society through constant interpretation and re-interpretations of the meanings of their actions and traditions.

Julius Soria (2012) says that the stories, myths, legends, poetry, and songs of the Ilokanos illuminate their character and disposition. Leopoldo Yabes (1936), who made "A Brief Survey of Iloko Literature," describes Pamulinawen to be one of the oldest and extant love songs possibly of pre-Spanish date. Several sources jestingly call it the Regional Song of the Ilocandia or the National Anthem of the Ilokano Nation since it is known practically by all the Ilokanos. The word pamulinawen is translated as "alabaster," which is a very hard stone or in another Iloko term, "layap." In the song, pamulinawen symbolizes the hard resistance of a woman (with a heart of stone or 
hardened heart) to her lover's courtship gestures. The lover, however, earnestly pleads to be noticed. As a folk song of the Ilokano cultural community, Pamulinawen carries the form of a "Polka" and the genre of being a light-hearted "Song of Love and Courtship."

As a qualitative type of research, this paper employs maiyannatup $a$ panagripirip as introduced by Danilo Alterado and Aldrin Jaramilla (2019). Literally, maiyannatup a panagripirip means "appropriate philosophizing." As a method or approach, it is focused on "philosophizing cultural life with prudence" since it seeks appropriate ways to comprehend the Ilokano metaphysics, epistemology, and axiology. More particularly, maiyannatup a panagripirip is a hermeneutic method that tries to unveil the meanings of the Ilokano life by aptly commencing, recognizing, and sustaining itself through the palpaliiw of Amador Foz (2001). Palpaliiw means observation, and it is the Ilokano counterpart of "existential phenomenology." Palpaliiw basically connotes a more profound curiosity of the Ilokanos' thoughts, feelings, sensations, images, and memories - their stream of consciousness - in the ordinary things they do. Palpaliiw practically takes on the things ignored about the ordinary Ilokano life because these have become mechanical. Doing philosophy in Ilokano, whether at the instance of an Ilokano researcher or from the vantage point of a non-Ilokano, always deals with the constant approach or strategy of observation. When the more often-ignored Ilokano spices of ordinary thoughts, feelings, beliefs, convictions, and other aspects of everydayness as vivified in their practices, literature, artisanship, and symbols are made objects of observation, definitely they reveal a wellspring of intuitions, notions, systems, and paradigms that have the same standing as the universally-acclaimed ones.

Maiyannatup a panagripirip also employs the lexicographic tool "Agcaoilon PAR." Lexicography, according to Akar Ahmed and Jamel Omar (2017), refers to the linguistic discipline to compile, write and edit dictionaries; it plays a significant role in the preservation, development, and enrichment of language. "Agcaoilon PAR" is a coined phrase to refer to Aurelio Solver Agcaoili's lexicographic methodology in his study of the Ilokano language, thus "Agcaoilon." "PAR" stands for "Punget-A-Ramut a balikas" (root-stem word) attached with either a panekket-rugi (prefix) or panekketungto (suffix) or both; it is the etymological approach of describing and understanding an Ilokano word. Simply stated, the conceptual movement from the punget-a-ramut a balikas shows other possibilities of understanding that could speak of the Ilokano substantively (See Agcaoili, 2016 and Soria, 2012). Therefore, the PAR as a tool helps to refloat the original meanings of some Ilokano words or terms from the lyrics of the song Pamulinawen by accommodating other associated core Ilokano concepts and thus unpack their rich and deeper derivative meanings that contribute in shaping up a character that speaks of the Ilokano beingness.

Pamulinawen is traditionally interpreted as a song about the beautiful yet stonehearted and hard-to-get Ilokano woman. The questions, nonetheless: Would the meaning and message of the song Pamulinawen just revolve within its traditional context? Can knowledge of the Pamulinawen be deepened and increased so that it transposes its stature from being simply a piece of Ilokano cultural song that provides entertainment and fixed interpretation exclusively about the Ilokano woman?

It can be initially construed that Pamulinawen does not only address the Ilokano woman but also yearns for every Ilokano as its beholder (reader/listener-interpreter) 
who gives it a new meaning and present-day importance. It is the Ilokano who can best give a new dimension, a new truth to Pamulinawen. This is on the basis that both Pamulinawen as the song and the Ilokano as the beholder is mediated by a common language (pagsasao) and are very much inspired by one identity or totality (nakem or kananakem). As Pamulinawen longs for the enhancement of its being or truth as a cultural or traditional Ilokano song (kanta-kannawidan) with the participation of the Ilokano beholder, the song in turn ushers the latter to visit himself or herself and evaluate whether or not he or she has remained the true Ilokano amidst identityshattering realities.

\section{PAMULINAWEN, ITS ORIGINAL INTERPRETATION, AND RE- INTERPRETATIONS}

Pamulinawen, pusoc, indengamman

Toy umas-asog, ag-rayo ita sadiam

Panunutemman, dica pagintutulngan

Toy agayat, ag-rucnoy ita emmam.

Essem ti diac calipatan

Ta nasudi unay a nagan

Ta uray sadin ti yan

Disso sadino man

Aw-awagac a di agsarday

Ta naganmo a casam-itan

No malagipcan

Pusoc ti mabang-aran.

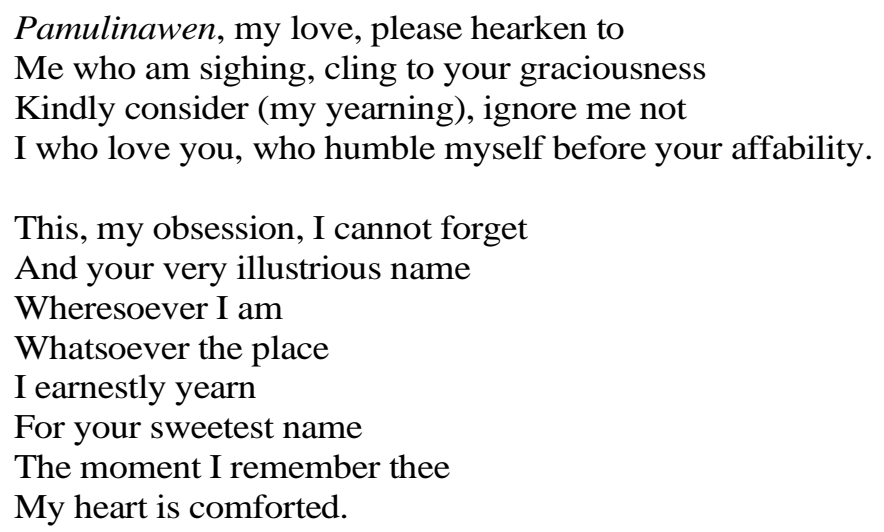

This is the famous refrain of the lyrics of Pamulinawen. ${ }^{2}$ Yabes (1936) argues that these Ilokano lines cannot be rendered into sensible English. Accordingly, translations of Iloko songs, poems, proverbs, riddles, etc., are not literal but free 
because some contain Iloko words and/or expressions that cannot be adequately rendered or cannot be translated at all into English. It goes without saying that Pamulinawen, through the years, has come in different versions, lyrics, and melodies. That is why a cursory review of the literature points not only to a single original composer or poet, or writer. ${ }^{3}$

Accommodation of the series of development or re-interpretations of the lyrics of Pamulinawen is an essential component of the hermeneutic approach to the Ilokano cultural work of art. Maiyannatup a Panagripirip, or the manner of appropriately or prudently philosophizing the Ilokano cultural way of life, aims to drive home an intelligible account of what Pamulinawen more comprehensively expresses. It does so by articulating the interplay between the speculative and the analytic dimensions of meaning. The interplay here offers a two-fold revelation: how Pamulinawen communicates effectively beyond what its composer and/or writer originally intended and how the Ilokano cultural meaning finds its way in. Indeed, this hermeneutic approach is not at all foreign from what Hans George Gadamer $(2013,474)$ in "Truth and Method" emphasizes on the dynamism of a word: "Every word has an inner dimension of multiplication; every word breaks forth as if from a center; every word causes the whole of the language to which it belongs to resonate." Previously, in "Text and Interpretation," Gadamer (1989, 43) posited: "With a literary text, the selfmanifestation of each and every word has a meaning in its sonority." Walter Brogan (2020) further explains that, by reason of the unity of a literary or poetic word resonating within itself the whole of language, the word eventually generates the text, much like the musical note in relation to the melody; the word is able to repeat itself and be heard as language in its very self-articulation.

The opening line of the song is "Pamulinawen, pusoc indengamman" (Pamulinawen, my love, please hearken to). The common interpretation for this line is that of a lover who pleads to be noticed by the woman with a heart of stone. Ironically, in its new interpretation, the song already addresses as "Pamulinawen," its listenerinterpreter. Stated simply, the song Pamulinawen entreats for recognition and enhancement from the one who can communicate with it. Thus, Pamulinawen, as a work of art, has the capacity for self-presentation. Hans Georg Gadamer (1976) affirms that a work of art says something in its self-presentation. It has a cognitive reality and legitimacy that makes it stand in its own right and gives it the expressive power to affect the beholder immediately. The work, Gadamer $(2001,71)$ claims, is an "Ereigniss" an event that "appropriates" to itself; it jolts us, knocks us over, and sets up a world of its own, into which we are drawn. Georg Lukacs (1978), in his work "Art and Objective Truth," goes further to stress that the work of art creates its own world that is distinct from everyday reality. A work of art, once fashioned in a certain form, has its own life. A new world emerges through all the details of the work. So, a necessary character intrinsic to art is the created world of the work of art. The experience of the work of art involves the interplay between the work of art and objective reality.

Another line of the song is "Toy umas-asog, ag-rayo ita sadiam. Panunutemman, dica pagintutulngan"' (Me who am sighing, cling to your graciousness. Kindly consider (my yearning), ignore me not.) As Pamulinawen makes a prior inner assertion of what it is, it also engages the Ilokano beholder to mindfulness of what he or she really is and struggles to assert that identity. Dialogue appears to be the other direction of these lyrics 
of the Pamulinawen. Pusoc indengamman (my love, please hearken to), the song's initiatory call of self-presentation or assertion, leads to a summon for dialogue, of being listened to [Panunutemman, dica pagintutulngan - Kindly consider (my yearning), ignore me not]. This alludes to what Gadamer (1976) dubs as "the hermeneutic dialogue," whereby there operates the consciousness of the work and that of its beholder simultaneously. Gadamer underscores that each party to the hermeneutic dialogue possesses an expressive power to elicit something from each other. This is because there is inherent meaning in the work and in the beholder. They are not empty containers into which meaning is poured on each of them the first time. Each has a truth or very being, which needs "re-tuning" through the process of interlocking for dynamic becoming. Here takes place what Gadamer (1989) speaks of as the "fusion of horizons."

Applying this to Pamulinawen, there is a constant discourse - interaction or collaboration - between the text or lyrics of this Ilokano folksong (tradition; culture the past horizon) and the reader/listener-interpreter (now; immediate experience - the present horizon). Understanding is continually expanding as the beholder, be it in his or her act of writing or lived experience, is exposed to dialogue with the text.

The remaining lines are "Toy agayat, ag-rucnoy ita emmam. Ta nasudi unay a nagan. Ta uray sadin ti yan, Disso sadino man, Aw-awagac a di agsarday, Ta naganmo a casam-itan. "(I who love you, who humble myself before your affability. And your very illustrious name. Wheresoever I am, Whatsoever the place, I earnestly yearn for your sweetest name). These lines show the character of the Ilokano. In the hermeneutic dialogue, the lyrics of Pamulinawen assert who the Ilokano is. Worthy of note then are the following words with their popular meanings: emmam, which is understood in the song as "affability"; nasudi, which is translated as "illustrious" or "pure" or "perfect" - the "absence of coarseness" (awanan kersang) or "absence of defect" (awanan kurang); nagan which stands for "name"; and casam-itan, which means "sweetest", or makaay-ayo la unay (most pleasing). Emilio Alvarez (1970) originally came out with a critical analysis of the song Pamulinawen. According to him, as George Gelade (1993) confirms, pamulinawen means flint, which is also known by the Ilokanos as "layap" - shooting star, falling star, bolide, fireball, and meteor. The article of Alvarez establishes that pamulinawen typifies particular and distinctive traits of the Ilokano:

\begin{tabular}{|c|l|l|}
\hline Trait & \multicolumn{1}{|c|}{ "Pamulinawen" } & \multicolumn{1}{c|}{ Ilokano } \\
\hline Migratory & $\begin{array}{l}\text { believed to be a chip of the } \\
\text { star that had migrated to the } \\
\text { earth from outer space } \\
\text { Dispersed } \\
\text { found in almost all parts of } \\
\text { the surface of the globe }\end{array}$ & $\begin{array}{l}\text { Ilokanos are one of the most migratory } \\
\text { people of the Philippines. }\end{array}$ \\
$\begin{array}{l}\text { Enduring } \\
\text { has endured the melting } \\
\text { heat and fire produced as it } \\
\text { diaversed the atmosphere of } \\
\text { the earth to reach its surface }\end{array}$ & $\begin{array}{l}\text { The Ilokano remains fundamentally as } \\
\text { Ilokano and is anywhere else enduring/ } \\
\text { "immutable" in character traits, in heart, } \\
\text { in soul, and in language. }\end{array}$ \\
\hline
\end{tabular}


Closely associated with the Ilokano "pamulinawen" character is kadagaaan, another core Ilokano concept. Gelade (1993) identifies daga to be the root-stem-word (PAR), which means land, earth, soil, or ground. "Kadagaan" (Ka+daga+an) indicates the finding of the ideal dwelling place for a person or family. The prefix "ka" in this usage connotes a superlative - "the best," or even better "the most good," similar to Iluko "ka-pintasan," meaning most beautiful (pintas - beauty) or "ka-imbagan" (the most good). Agcaoili (2018, 1-26) invokes the idea of finding a promised land for oneself and for the family. In his socio-historical novel "Dangadang," he (2003) depicted how the Agtarap family migrated to Mindanao to take part in the "land of promise" narrative of the government, yet only to find out that the said place is not their "kadagaan"; thus they decided to migrate and search for their rightful place "their kadagaan" - in Isabela. This further explains the migratory, dispersed, and enduring character traits of the Ilokanos in finding their dwelling place - their kadagaan. Moreover, in their searching and settling in their "promised land," they are expected to be pamulinawen.

For Alterado and Jaramilla (2019), the Ilokano culture is very much alive to prove the enduring character of the Ilokano's kinatao or worth. ${ }^{4}$ An Ilokano, Yabes (1936) wittingly said, can go anywhere, penetrate into a strange territory and get along well and make friends with everybody. Selected stanzas from several poems likewise furnish the frame for the canvass of the Pamulinawen's (Ilokano's) identity as embedded in the song Pamulinawen:

Ilocano, Modelo ti Amin a Filipino (Quilpa, 1999).
Sadino man, O Ilocano, ti ayanmo
Asidegka man wenno addaka't adayo
Sika latta ti agnanayon a maital-o
Ta ti naganmo ket nabileg ken nabanglo.

\section{Ilocano (A Model for All Filipinos)}

Wherever you are, Oh Ilocano

Whether you are near or far

It is you who is to be praised forever

Because of your genuine and sweet name.

Any kind of work you embrace

Because it is your will to brave through life

Formidable body and solid faith you have

You are a model of the Filipino and other races.

Through resolute mindfulness, the Ilokano is able to sustain a "pure identity" because of his "universal" and "solid" character of being a pamulinawen.

At this point, new meanings may already be inferred for some terms in the lyrics of Pamulinawen with the aid of Agcaoili's (2011) Contemporary English-Ilokano Dictionary: 
As "affability," emmam in relation to the Ilokano identity entails "friendliness" and "attractiveness," which expands its meaning to kinainfluensia (strong influence); kinaadda ti kababalin a mangpaasideg iti sabali (easy to get along well with either friends or strangers); karisma (charm, charism); kinalaing a mangukkon kadagiti tattao (skillful at bringing people together).

If nasudi means "illustrious" or "pure" or "perfect," it is, therefore, "natan-ok" or natakneng (dignified).

Not merely "name," nagan is the embodiment of the Ilokano kinatao (personhood). Thus, nasudi a nagan (illustrious or pure or perfect name) is natan-ok or natakneng a kinatao (dignified personhood).

Being "sweetest" and "most pleasing," casam-itan aptly adjectivizes the dignified personhood of the Ilokano as ingungoten/ilalaen; ikkan iti importansia/pateg ("worth-cherishing" or "worth-valuing").

The preceding hermeneutic treatment and analysis of Pamulinawen, which showcases the fusion of the dynamism inherent in both text and reader/listenerinterpreter, exemplifies the method of intersubjective knowledge in Ricoeur's theory of interpretation. Paul Ricoeur (1991) speaks of the process of opening the world of the text to the world of readers in different milieus and contexts- thereby exposing such text to the possibilities of diverse, different interpretations. ${ }^{5}$ In this fashion, the text and its interpretation do not exclusively and permanently reside with the author. Susan Goldman et al. (2015) stipulate that texts invite the reader to adopt an interpretive stance. In their work "The Intentional Fallacy," William Kurtz Wimsatt and Monroe Beardsley (1946) come with the provocation that a poem does not belong to its author but rather at birth it is detached from the author who goes about the world beyond his or her power to intend about it or control it. Understandably, the poem belongs to the public." ${ }^{6}$ Recognition should then be accorded to the interplay between the knowledge of the author and the understanding of the interpreter or between the epistemology (of the author) and the ontology (of the interpreter). Reinterpreting today the traditional folksong Pamulinawen as constituting in a broader sense the Ilokano cultural self-understanding exhibits the process of making sense of a past object of aesthetics within the realm of the contemporaneous, evolving life of the Ilokano.

The line "Toy umas-asog, ag-rayo ita sadiam" (Me who am sighing, cling to your graciousness) implies an act of "clinging to" (kumarayo) accompanied by a disposition of "crying in pain" (panag-asog). No malagipcan, Pusoc ti mabang-aran (Every time I remember you, My heart beats a sigh of relief) depicts the "soothing experience" (pannakabang-ar) brought about by the thought or memory (panang-lagip) of the Ilokano someone or Ilokano Other. The interrelation of Iluko root-stem-words (PAR) "asog" (painful crying/feeling), "rayo" (clinging/yearning), "lagip" (memory/thought), and "bang-ar" (soothing/satisfying) makes up the essential notes of and the coping up mechanisms to the Ilokano experience of "iliw" (longingness). These lines in the lyrics 
of Pamulinawen form an epistemology as they articulate the philosophy of nostalgia or homesickness. Pino Blasone (2018), citing the Swiss doctor Johannes Hofer (1688) as the originator, presents "nostalgia" as a neologism from the ancient Greek roots "nostos," meaning "return (home)" and "algos," "sorrow" or "suffering."7

However, the Ilokano "iliw" or nostalgia is not a mental malady, as contemplated by Hofer. It is more of "a philosophical mood," adopting the term of Blasone (2018) and one that carries an existential impetus for it to serve as "an enabler of self-continuity," following the thought of Constante Sedikides et al. in Fabio Sani (2008). When the Ilokano who works abroad or is in diaspora yearns (ag-rayo) for native land, there props up from within the habit of longing (pannaka-iliw) for the graciousness (sadiam) of his or her cultural identity and the things he or she used to do in the past. This nostalgia is a natural, frequent painful feeling (umas-asog), yet it is correspondingly resolved or soothed (mabang-aran) when he or she arrives at the thought (malagip) of a fellow Ilokano or of his or her sustained Ilokano self in the midst of identity-distorting circumstances. An Ilokano daniw (poem) reinforces the above re-interpretations:

Nakairuaman ni Ilocano (Quilpa, 1999)

\author{
Sadino man ti ayan \\ Lugar a nakayanakan, \\ Dimmakelan wenno nakaikamangan, \\ Pagtrabahuan wenno pagindegan \\ Asideg man wenno adayo \\ Mailiw latta ni Ilocano \\ Kadagiti nakaisigudanna \\ Biag a nakairuaman na...
}

What the Ilocano is used to

'Wherever he is

Be it at his birthplace,

Where he grew up or where he is married,

Workplace or home

Whether near or far

The Ilocano always longs

For things familiar to him

The life he's been used to living ...'

Precisely, the Ilokano philosophy of nostalgia concretely elucidates the standpoints of John Tierney (2013), quoting Clay Routledge and Erica Hepper, respectively, in his article "What Is Nostalgia Good For? Quite a Bit, Research Shows ": “...[T] he feeling of discontinuity does not seem to be a typical result of nostalgia ... In fact, people tend to have a healthier sense of self-continuity if they nostalgize more frequently..."; "[n]ostalgia serves a crucial existential function" because it "helps people deal with transitions." The underpins of Ilokano philosophy of "iliw" is reasserted in a more vivid way if the paper "Nostalgia as Enabler of Self 
Continuity" by Sedikides et al. (2008) is to be appropriated. Following the thought of David R. P. Wiggins (2001) in "Sameness and Substance Renewed," they argue that continuity serves as a presupposition of identity. They proceed to elaborate: Nostalgia is "a sentimental longing or wistful affection for the past" (New Oxford Dictionary of English, 1998). By being primarily a positive emotional experience or a self-relevant emotion as such that increases self-positivity while sustaining social connectedness, ${ }^{8}$ nostalgia carries existential meaning in efforts to protect the integrity of the self by serving as an enabler of self-continuity. It develops in the individual the value of fortitude; it serves as a reservoir of helpful memories and experiences needed to manage and cope with an existential threat.

\section{PAMULINA WEN AND THE ILOKANO LANGUAGE}

Pamulinawen possesses an element that gives distinctiveness to its nature as a work of art. Culturally pillared as a work of art, Pamulinawen is a kannawidan (cultural practice or tradition). The root-stem word (PAR) of kannawidan is "tawid," meaning inheritance or heritage. Generally, it is used to refer to the Ilokano culture. ${ }^{9}$ On this premise, Pamulinawen has essential relevance to the Ilokano reader/listenerinterpreter. It has the capacity to present or assert itself to its beholder since it consists of a communally constituted language which the latter does also speak. Eventually, its language cajoles the beholder to understand it and look deeper into what it is saying.

The role of the Ilokano language cannot be disregarded in doing the hermeneutics of Pamulinawen. Agcaoili (2015) takes pride in the role of the Ilokano language. He emphasizes that the many ways of plumbing into the depths of the indigenous knowledge of the Ilokanos are mediated by the people's language. He drives home poignantly that,

... we do not own language in a philosophical sense. Instead, language claims us - owns us. It is through language that we are known - collectively identified: we are Ilokano precisely because the Ilokano language mediates us. It is a marker - and the first marker. And this first marker is for life. We cannot run away from this mark however much we try.

History itself is a living attestation that the language of the Ilokano is intertwined with the ontology of the Ilokano self: Ilokanos refer to themselves as Samtoy, a contraction from the Ilokano phrase "sao mi ditoy" - our language here ("Who are the Ilocanos?"). ${ }^{10}$ Hence, for Pamulinawen as a work of art and its listener-interpreter to consistently gain situated meanings, they must always be in a mediated relationship; they have to relate in and must constantly be confronting Ilokano language a vehicle of their meaning.

Nevertheless, it must be noted that the general characteristic of the Ilokano language makes it at home with hermeneutics; it is susceptible to interpretations. In the realm of Ilokano literature, for instance, the Ilokano writer or composer views his works as an extension of his own self. But while the Ilokano language serves to 
embody the Ilokano identity of the literature's originator, it nonetheless assists the core identity of the ensuing reader-interpreter to become an adaptable and flexible identity so that it can produce situated meanings. This is so because the author leaves to the reader room for contextual interpretations.

In the act of building and justifying interpretations of texts, Paul Deane (2020) has this to say: "The power of a literary work depends on its ability to move a wide range of readers who may approach the text from widely varying perspectives." Deane $(2020,12)$ calls this "literary reasoning," "a distinct kind of thinking with distinct epistemological properties" since it "is concerned with understanding how literary texts communicate insights about the human experience; assumes complexity and ambiguity of meaning; builds interpretive arguments based on textual and contextual evidence; is open to multiple interpretations."

The inseparability of Pamulinawen as culture per se, the Ilokano identity, and the Ilokano language alludes to the argument of Lourdes Rovira $(2008,66)$ that "[1] anguage is intrinsic to the expression of culture"; therefore, it "is a fundamental aspect of cultural identity" inasmuch as it has "the power to define and shape the human experience" and thereby serves as "a complicated dance between internal and external interpretations of identity." This is where the emancipatory experience of aesthetic dialogue lies. In and through language, the reader/listener-interpreter of the lyrics of Pamulinawen is required to understand them. Moreover, because the lyrics have a lot of "something to say," the reader/listener-interpreter actively plays along with the words or language of the folksong, allows some forms of other meanings to emerge from them and, in the long run, enhances the value of Pamulinawen. In turn, the Ilokano beholder of Pamulinawen comes to new realizations, especially along with cultural identity or cultural self-understanding.

\section{PAMULINAWEN AND NAKEM}

Bringing Pamulinawen into the hermeneutical process reminds not only of its very close association with the Ilokano language but also leads to the direction of Nakem.

"Nakem" is an Ilokano term that refers to the sense of interiority or sense of personhood; thus, the term "Nakem" embodies the core of being an Ilokano. The word nakem is the most comprehensive indigenous term that renders the Ilokano interiority, the core and the worth of one's personhood. Etymologically, as presented by Alterado (2015), the Ilokano prefix " $n a$ " indicates fullness, as in $n a+i m b a g$ (good), hence, it means fullness of the good; and the Ilokano suffix "kem" is suggestive of one's interiority; likewise, the word "akem" refers to one's role and responsibility in the community.

Agcaoili (2016) makes it clear that nakem is about the Ilokano's totality (kinatao). For that reason, it neither pertains exclusively to mind or thinking nor is it just one of the Ilokano's common faculties. Alterado (2012) uses the concept of "cosmic nakem" to capture and embody the Ilokano sense of being, his interiority, the core, and the worth of his personhood, which is always interrelated with the cosmos, with the environment. The intellectual, volitional, psychological, emotional, ethical, spiritual as well as social aspects are interconnected and altogether operate in nakem. 
This nakem prototype epitomizes in his what Katrina De Guia $(2005,233)$ terms as the "harmonic assimilation of opposites."

Alterado and Jaramilla (2019) infer that nakem bespeaks the Ilokano ontology or philosophy of being. Hence, any attempt to understand the Ilokano ontology of the self cannot escape ruminating on nakem. The Ilokano has an ontology of self that is engendered from his culture because nakem is one culture resource that makes sense of the Ilokano life. This is how the pathway of the hermeneutics of Pamulinawen leading straight to the ontology of Nakem be argued logically: If Pamulinawen expresses the Ilokano, then it also expresses kinatao. If Pamulinawen is a vital part of the Ilokano's kinatao, then it is likewise a substantial component of the inclusive nakem. If what mediates the constant becoming of Pamulinawen is language, then it similarly what ushers the continuing formation of the ontology of nakem.

The core of the Ilokano's existence is the becoming of his or her kinatao. It is the Ilokano language that helps unravel the centrality of this project. Many Ilokano arts and literature such as poems (daniw), songs (kankanta), proverbs (pagsasao), and the like bring home the message about the integral formation of the Ilokano self.

Alterado (2015, 182), citing Agcaoili (2013), emphasizes that what guides and inspires the ongoing development of kinatao is Nakem, a deep-seated reality that captures "the Ilokano sense of being, his interiority, the core and worth of his personhood." It is as well that which contains the ideals of the Ilokano as a person.

Nakem, indeed, is inclusive because it is the Ilokano's totality - ti pakabuklan ti kinatao na. Thus, the Ilokano Ontology of the Self is no other than the self which is grounded on Nakem. Self-understanding for Ilokano is understanding the self as grounded on Nakem.

\section{CONCLUSION}

Is Pamulinawen just a plain and simple Ilokano song? Is Pamulinawen exclusively a term for an Ilokano woman? Is Pamulinawen the name of that Ilokano woman? Why has Pamulinawen been labeled as the Regional Song of the Ilocandia or National Anthem of the Ilokano Nation simply because it is the most-sung of the Ilokano classical songs? Or, is there something deeper in the song that makes it the most qualified regional song or national anthem of the Ilocandia? Why has Pamulinawen become a generic term - now used in many ways like Pamulinawen Festival, Pamulinawen Motif or Inspired, Pamulinawen Melody (like Salidummay), etc.?

There are matters casually ignored that need to be examined or re-examined to separate what is evidently given from what is merely associated with it. There is a wealth of reference in the cultural arts of the Ilokanos, which unpack their contribution to the common heritage of human wisdom. The Ilokano kinatao (personhood) is more often envisaged through music and/or songs. Whenever the Ilokano experience is romanticized in arts, literature, and symbols music, what is conveyed are not merely simple thoughts but also illustrations of Ilokano-ness. Hence, the Ilokano writer and/or composer wants to be understood, desiring that work be treated with practical usefulness by serving as a philosophical explication of consciousness. 
Pamulinawen, which has been traditionally known as an Ilokano classical song of love and courtship, no less conveys the Ilokano Being or Identity as Pamulinawen. The hermeneutical process through Maiyannatup a Panagripirip has brought to the fore Pamulinawen's transformative hermeneutic dynamism. Among others:

1.Pamulinawen is not just a song that entertains. It basically embeds the ontology, epistemology, and axiology of the Ilokanos. The philosophy of the Ilokanos, which is often a tacit philosophy grounded on practical consciousness and normally expressed in cultural life and their representations, has found an illustration of its discursive consciousness and form in aesthetics. Because of its cognitive element and its experiences, Pamulinawen is a song that discourses in the realm of philosophical traditions.

2. The possibilities of the lyrics of Pamulinawen for new interpretations refresh and resurface many things about the Ilokano, or simply "Ilocano-ness." Pamulinawen (the culturally-grounded song which has the expressive power) addresses "Pamulinawen" (the Ilokano beholder/reader-listener who engages in interpretation and re-interpretations) to realize situated meanings. By singing the song, the Ilokano does not just preserve the song for history or mementos' sake. He or she sings the song because he or she owns the song. He or she sings in order to find possibilities for his or her identity. In a nutshell, he or she sings the song because he or she is the song.

Pamulinawen is said to be the "Regional Song of the Ilocandia" or "National Anthem of the Ilocano Nation." Be it so; the Ilokano is Pamulinawen.

\section{NOTES}

1. Traditionally, they are referred to as the descendants of Austronesian-speaking people from southern China via Taiwan, whose native domain was the narrow northwestern coast of Luzon directly facing the South China Sea. They were originally called "Iloko," a word derived from the prefix " $T$ " - meaning "people of" and "lokong" referring to the low-lying terrain. The Iloko, therefore, are "people who dwell in the lowland," as opposed to the "Igolot" who are people of the "gulot" or mountains, specifically the Cordillera mountain range (See Alvarez 1969, 143;149). Other sources state that the term Ilokano originates from I ("from") and looc ("cove or bay"), thus "people of the bay." Ilocanos also refer to themselves as Samtoy, a contraction from the Ilokano phrase "sao mi ditoy" (our language here). Today, the "Iloko" as the original name of the inhabitants is now used to refer to the language (sometimes spelled "Iluko") while "Ilokano" refers to the people or the ethnicity of the people who speak the Iloko language. Ilocano is the hispanized adaptation of the original name "Iloko" or "Ilokano." Writers use "Ilocano" and "Ilokano" interchangeably.

In this paper, however, "Ilokano" refers to the person who speaks the Ilokano or Iloko of the northern region, spoken as a secondary language by more than two million people who are native speakers of Pangasinan, La Union, Ilocos Sur, Ilocos Norte, Abra, Benguet, Cagayan, Isabela, Nueva Vizcaya and others in Northern Luzon. These 
Iloko-speaking people are sometimes referred to as the Amianan peoples. The new meaning and extent of "Amianan peoples" includes the Ilokano-speaking people in the other Ilokanized provinces of the Philippines such as Zambales and Mindoro and elsewhere in the Central and Southern Philippines where there are Ilokanos. Needful to include here are those in the diaspora.

2. This version of the lyrics of Pamulinawen has been the result of Alvarez's many months of research, study, and comparison. For him, this is free from corruption, and it is believed to be nearest to the original. Its English version was also the free translation of the song by Alvarez. See Emilio Alvarez (1970), "A Critical Analysis of Pamulinawen, the Regional Song of Ilocandia,” Ilocos Review, 17-27.

3. Some references claim Jose A. Bragado (1975), a writer and poet born at Santa, Ilocos Sur, to be the composer of the Pamulinawen. Visit https://www.academia.edu.

4. See also Aldrin S. Jaramilla (2015). "Panagsangaili": Exploring the Philosophy of Ilokano Hospitality. A Thesis submitted to the School of Advanced Studies of the Saint Louis University of Baguio City in partial fulfillment of the requirements for the degree Master of Arts in Philosophy, 107.

5. Following Gadamer, Ricoeur elaborates the concept of "distanciation". There occurs the communication on the distant, the near and the open between two differently situated consciousness that takes place by means of the fusion of their horizons. Hence, there is living neither within closed horizons nor within one unique horizon. In the process of convergence, nonetheless, there remains the interplay of differences, so each remains distinct from the other. (See Paul Ricoeur, The Task of Hermeneutics in A Ricoeur Reader: Reflection and Imagination ed. Mario J. Valdes. New York: Harvester Wheat Sheaf, 1991).

6. In the hermeneutic treatment of a work of art or literature, the reader's impression of the author's intent is a working force in interpretation. The author's original or actual intent is not a working force because, as such can hardly be fully recovered and therefore immaterial. However, being immaterial does not necessarily mean it is already rendered useless. The author's intent, notwithstanding it is no longer a working force in interpretation, may still help filter insignificant interpretations of a work. (See the standpoint of Wimsatt, W. K. and M. C. Beardsley on "The Intentional Fallacy" in Authorial Intent, at https://en.wikipedia.org.).

7. "Nostalgia" is a neologism coined by the Alsatian student Johannes Hofer (1669-1752) at the University of Basel in Switzerland, specifically in his Medical Dissertation on Nostalgia, or Homesickness. (See Pino Blasone (2018), "Nostalgia, as a philosophical mood," at https://www.linkedin.com.).

8. Sedikides, Wildschut, \& Baden (2004) conceptualize nostalgia as a selfrelevant emotion. They regard the self as the central character of the nostalgic episode while endorsing the view that the self operates in the social context (See also Sedikides, Wildschut, Arndt, \& Routledge, 2006).

9. Alterado and Jaramilla (2019, 98-99), in their paper "Maiyannatup a Panagripirip: Towards an Ilokano Indigenous Doing of Philosophy," describes kannawidan as a variant of the Ilokano word tawid, meaning 
heritage or inheritance. Others translate it as cultural practice or tradition or kaugalian or kadawian. In short, kannawidan stands for the "Ilocano culture" (Savellano, 2009). By being synonymous with culture, kannawidan is understood in a new perspective (Mercado, 1994), where it includes not only folk traditions or traditional cultural activities and facets but also the entire spectrum of organized human activities ordinarily occurring in the context of social institutions. Hence, "tay nakairuaman wenno nakasanayan nga araramiden ti maysa a tao" (those undertakings a person is inclined to doing or, simply, the Ilokano's lived experiences) as explicated in traditions and practices, values and traits, language and literature, and in arts and symbols.

10. See https://ilocanoculture.wordpress.com.

\section{REFERENCES}

Agcaoili, Aurelio S. 2018. Nakaparsuaan, kadagaan, and panaglunit ti daga: Climate justice and environmental ethics in Ilokano life. Budhi 22 (3), pp. 1-26.

Agcaoili, Aurelio S. 2015. (En)visioning emancipatory consciousness: The tasks, directions and challenges ahead. In Aro Ken Sirmata: Language, Culture, Education, and the Pursuit of Diversity. Edited by Aurelio Solver Agcaoili and Elizabeth A. Calinawagan. Philippines: Nakem Conferences Philippines and Undertow Books, pp. vii-xvii.

Agcaoili, Aurelio S. 2016. Balabala ti filisopia nga Ilokano. Honolulu, Hawaii: Undertow Books.

Agcaoili, Aurelio S. 2016. Sanut ken wayawaya - The case for an Amianan people's philosophy of knowledge, freedom, and the good life. A Keynote Address at the Philosophical Association of Northern Luzon Conference at Mariano Marcos State University, Batac City, Ilocos Norte on February 12, 2016.

Agcaoili, Aurelio S. 2011. Contemporary English-Ilokano dictionary. Quezon City, Philippines: Cornerstone of Arts and Sciences.

Agcaoili, Aurelio S. 2003. Dangadang. Quezon City: University of the Philippines Press.

Ahmed, Akar and Jamel Omar. 2017. The role of lexicography in enrichment and development of language. ResearchGate. Available at https://www.researchgate.net. Accessed: December 6, 2020.

Alejandro, Rex Belli. 2015. Panagtagikua ken panagparangarang: Contextual panagmennamenna and doing philosophy in Ilokano. In Aro Ken Sirmata: Language, Culture, Education, and the Pursuit of Diversity. Edited by Aurelio Solver Agcaoili and Elizabeth A. Calinawagan. Philippines: Nakem Conferences Philippines and Undertow Books, pp. 87-103.

Alterado, Danilo S. and Aldrin S. Jaramilla. 2019. "Maiyannatup A Panagripirip:" Towards an Ilokano indigenous doing of philosophy. Philosophia: International Journal of Philosophy 20 (1), pp. 97-110. Available at https://www.pnprsphilosophia.com and https://c4fb26e2-a44c-4aea-96c2-

74fd10a43d0e.filesusr.com. 
Alterado, Danilo S. 2015. Nakem ken ulimek: A hermeneutics of silence in the Ilokano cosmic self. In Aro Ken Sirmata: Language, Culture, Education, and the Pursuit of Diversity. Edited by Aurelio Solver Agcaoili and Elizabeth A. Calinawagan. Philippines: Nakem Conferences Philippines and Undertow Books, pp. 104-122.

Alterado, Danilo S. 2012. Aquinas and discoursing on the Ilocano cosmic nakem. ACTA, Proceedings of the Quadricentennial International Philosophy Congress. Edited by Alfredo P. Co and Paolo A. Bolanos. Espana, Manila, Philippines: UST Publishing House.

Alvarez, Emilio L. 1970. A critical analysis of "Pamulinawen," The regional song of Ilocandia. Ilocos Review 2 (1), 17-27.

Blasone, Pino. 2018. Nostalgia, as a philosophical mood. Available at https://www.linkedin.com. Accessed: March 7, 2021.

Brogan, Walter. 2020. Basic concepts of hermeneutics: Gadamer on tradition and community Duquesne Studies in phenomenology. Hermeneutics Today 1 (1), pp. $1-12$.

Deane, Paul. 2020. Building and justifying interpretations of texts: A key practice in the English language Arts. ETS Research Report Series. Available at https://doi.org/10.1002/ets2.12304. Accessed: May 2021.

De Guia, Katrina. 2005. Kapwa: The self in the other, worldviews and lifestyles of Filipino culture-bearers. Pasig City, Philippines: Anvil Publishing, Inc.

Foz, Amador. 2001. Palpaliiw. Vigan, Ilocos Sur, Philippines: Vigan Printing Press.

Gadamer, Hans-Georg. 2013. Truth and method. New York, Bloomsbury Academic Press. In Walter Brogan. 2020. Basic concepts of hermeneutics: Gadamer on tradition and community. Duquesne Studies in Phenomenology, Hermenuetics today 1 (1), pp. 1-12.

Gadamer, Hans-Georg. 2001. Gadamer in conversation: Reflections and commentary. Edited and translated by Richard E. Palmer. Dutt., New Haven: Yale University Press.

Gadamer, Hans-Georg. 1989. Text and interpretation. In Dialogue and Deconstruction: Gadamer-Derrida Encounter. Edited by Diane Michelfelder and Richard Palmer. Albany: SUNY Press, 43. In Walter Brogan (2020). Basic Concepts of Hermeneutics: Gadamer on Tradition and Community. Duquesne Studies in Phenomenology. Hermenuetics today 1 (1), pp. 1-12.

Gadamer, Hans-Georg. 1989. Truth and method. $2^{\text {nd }}$ rev. Edited by Joel Weinsheimer and Donald G. Marshall. New York: Continuum.

Gadamer, Hans-Georg. 1976. Philosophical hermeneutics. Edited by D. Linge. Berkeley: University of California Press.

Gelade, George. 1993. Ilokano-English Dictionary. Quezon City, Philippines. CICM Missionaries, Inc.

Goldman, Susan R., Kathryn S. McCarthy, and Candice C. Burkett. 2015. Interpretive inferences in literature. In E. J. O'Brien, A. E. Cook, \& R. F. Lorch, Jr. (Eds.). Inferences during reading. Cambridge University Press, pp. 386-410.

Lukacs, Georg. 1978. Writer and the critic and other essays. Translated by Arthur Kahn. London: Merlin Press. 
The New Oxford Dictionary of English. 1998. Edited by Judy Pearsall and Patrick Hanks. Oxford University Press.

Quilpa. Cresencio. 1999. Ilocano, modelo ti amin a Filipino. Samtoy 1 (2). The Original English-Ilocano Magazine. Published by the Tawid ti Ilocos Foundation, Inc. Vigan City, Ilocos Sur, Philippines.

Quilpa. Cresencio. 1999. Nakairuaman ni Ilocano. Samtoy 1 (2). The Original EnglishIlocano Magazine. Published by the Tawid ti Ilocos Foundation, Inc. Vigan City, Ilocos Sur, Philippines.

Ricoeur, Paul. 1991. The task of hermeneutics. In A Ricoeur Reader: Reflection and Imagination Edited by Mario J. Valdes. New York: Harvester Wheat Sheaf.

Rovira, Lourdes C. 2008. The relationship between language and identity: The use of the home language as a human right of the immigrant REMHU. Revista Interdisciplinar da Mobilidade Humana 16 (31), pp. 63-81. Available at https://www.redalyc.org. Accessed: March 6, 2021.

Sedikides, Constante, Tim Wildschut, Lowel Gaerner, Clay Routledge, and Jamie Arndt. 2008. Nostalgia as enabler of self-continuity, In Self Continuity, Individual and Collective Perspectives. Edited by Fabio Sani. New York: Psychology Press, Taylor \& Francis Group, pp. 227-239. Available at http://www.southampton.ac.uk. Accessed: April 26, 021.

Soria, Julius B. 2012. Paka (Sarita)an: On Ilokano language, identity, and heritage education. A dissertation submitted to the Graduate Division of the University of Hawai'i at Manoa in partial fulfillment of the requirements for the degree of Doctor of Philosophy in Education.

Tierney, John. 2013. What is nostalgia good for? Quite a bit, research shows. New York Times. Available at https://www.nytimes.com. Accessed: May 7, 2021. (Please provide pages)

Who are the Ilocanos? (2017). Ilocano: The northerners of Luzon (Wonders of the cultures and traditions of the Ilocano community). Available at https://ilocanoculture.wordpress.com.Wonders. Accessed: November 2019.

Wimsatt, William Kurtz and Monroe C. Beardsley. 1946. The intentional fallacy. The Sewanee Review 54 (3), pp. 468-488. JSTOR 27537676. Revised and republished in The Verbal Icon: Studies in the Meaning of Poetry. University Press of Kentucky, 1954.

Yabes, Leopoldo Y. 1936. A brief survey of Iloko literature: From the beginnings to its present development, with a bibliography of works pertaining to the Iloko people and their language. Manila, Philippines: Oriental Printing. 